\title{
DEKONSTRUKSI TOKOH DUA ROMAN ANGKATANBALAI PUSTAKA DALAM NOVEL TRILOGI SOEKRAM (B AB PENGARANG TAK PERNAH MATI) KARYA SAPARDI DJOKO DAMONO
}

\author{
Yayuk Kurniawati ${ }^{1}$, M. Sukri ${ }^{2}$, Nuriadi $^{3}$ \\ Prodi Magister Pendidikan Bahasa Indonesia, Universitas Mataram
}

\begin{abstract}
Abstrak
Penelitian ini bertujuan menguraikan dekonstruksi tokoh dua roman Angkatan Balai Pustaka, yaitu roman "Siti Nurbaya" dan roman "Salah Asuhan" dalam novel "Trilogi Soekram” khususnya Bab III 'Pengarang Tak Pernah Mati' karya Sapardi Djoko Damono. Data penelitian diperoleh melalui metode kepustakaan. Analisis data dilakukan dengan menerapkan teori dekonstruksi. Hasil analisis menunjukkan bahwa terdapat dekonstruksi tokoh dalam novel "Trilogi Soekram" khususnya Bab III 'Pengarang Tak Pernah Mati' karya sapardi Djoko Damono. Tokoh-tokoh yang dihadirkan dalam novel tersebut merupakan dekonstruksin terhadap tokoh-tokoh yang ada dalam dua roman angkatan Balai Pustaka yaitu Siti Nurbaya dan Salah Asuhan seperti Datuk Meringgih, Siti Nurbaya, dan Hanafi. Tokoh-tokoh tersebut didekonstruksi karakternya, bahkan tokoh dari dua roman yang berbeda dipertemukan dalam 'Pengarang Tak Pernah Mati'. Hal tersebut menunjukkan bahwa sesuai dengan konsep dekonstruksi, makna sebuah teks tidak pernah berdiri sendiri dan tidak pernah mutlak.
\end{abstract}

\section{Kata kunci: dekontruksi, tokoh, novel}

\section{A. PENDAHULUAN}

Sastra memiliki hubungan yang erat dengan kehidupan manusia. Sastra menjadi salah satu bagian dari khasanah pemikiran manusia. Sastra telah hadir sejak manusia mengenal dunia, mulai dari dongeng-dongeng masa kecil yang diceritakan di lingkungan keluarga, cerita rakyat yang dikenalkan oleh lingkungan masyarakat sekitar, dan bentuk lain karya sastra yang hidup dan berkembang dalam masyarakat dari waktu ke waktu.

Pada awalnya, sastra dilihat sebagai sebuah objek dan penikmat sastra sebagai subjek. Dalam perkembangannya, seorang pembaca atau penikmat sastra melakukan analis is terhadap karya sastra tersebut dengan berbagai cara atau metode. Pengalamanpengalaman di sekolah, misalnya, membuat seseorang mengenal sastra melalui metode yang diperkenalkan oleh guru, sehingga pembaca akan me mandang dan menyimpulkan karya sastra itu berdasarkan pola-pola yang sudah ada atau yang telah dipelajari. Hal itu umumnya bersifat statis dan monoton. Ketika diminta untuk menganalis is nya, misalnya, 
siswa atau pembaca akan langsung berpikiran mengenai struktur intrinsik karya tersebut. Padahal ada sisi lain, ada hal yang lebih dalam yang bisa digali, yang sebelumnya tak terlihat, dan yang mungkin saja menjadi esensi dari karya tersebut.

Seiring berkembangnya teori sastra, maka muncullah sebuah istilah yang disebut dengan dekonstruksi, sebuah istilah yang memungkinkan kita membe dah karya sastra dengan cara yang berbeda, dengan meruntuhkan anggapan yang sudah umum, dan membangunnya kembali dengan apa yang disebut dengan isi yang sesungguhnya, hal yang tersembunyi dari karya tersebut, yang luput dari penglihatan selama ini. Dekonstruksi membawa hawa baru dalam pergelutan di bidang sastra. Derrida (dalam Ratna, 2011: 222) mengemukakan bahwa teori dekonstruksi adalah penolakan terhadap logosentrisme dan fonosentris me yang secara keseluruhan melahirkan opos isi biner dan cara-cara berpikir lainnya yang bersifat hierarkis dikotomis.

Penciptaan karya sastra oleh pengarang juga berkembang seiring perkembangan pemikiran dan kreativitas manusia. Pengarang tidak hanya menciptakan sastra berdasarkan kebiasaan-kebiasaan yang ada. Pengarang juga melakukan inovasi saat menciptakan karyanya. Pengarang melakukan sesuatu yang berbeda dengan kebiasaan pengarang lain. Bahkan pengarang bisa 'merombak' karya sastra yang ada dengan melakukan dekonstruksi terhadap karya tersebut.

Salah satu karya sastra yang menunjukkan adanya dekonstruksi adalah novel Trilogi Soekram karya Sapardi Djoko Damono. Dalam novel ini, khusus nya bab III 'Pengarang Tak Pernah Mati', Sapardi Djoko Damono melakukan dekontruksi terhadap tokoh-tokoh yang ada dalam beberapa roman Angkatan Balai Pustaka, misalnya tokoh Datuk Meringgih, Siti Nurbaya, dan Samsulbahri dalam roman Siti Nurbaya karya Marah Rusli, serta tokoh Hanafi dalam roman Salah Asuhan karya Abdul Muis. Bahkan tokoh-tokoh dalam dua roman yang berbeda tersebut dijadikan dalam satu keluarga, seperti Nurbaya (identik dengan Siti Nurbaya dalam roman Siti Nurbaya ) dan Hanafi (identik denga tokoh Hanafi dalam Salah Asuhan) dijadikan dua tokoh yang kisahkan bersaudara dalam novel Trilogi Soekrom. Lebih jauh lagi, Sapardi Djoko Damono juga menyinggung roman lain kisahnya identik yaitu Anak Perawan di Sarang Penyamun karya Sutan Takdir Alisyahbana. Karakter perorangan juga ditampilkan Sapardi sebagai tokoh dalam novel Pengarang Tak Pernah Mati, yaitu tokoh Kartini yang karakternya mirip R.A. Kartini, tokoh emansipasi wanita Indonesia. 
Tokoh-tokoh sentral dalam roman dan karakter tertentu tersebut dijadikan sebagai tokoh dalam novel Pengarang Tak Pernah Mati, kemudian diubah atau didekonstruksi karakternya oleh Sapardi Djoko Damono. Mereka dilibatkan pula dalam alur cerita yang juga didekonstruksi. Bahkan pada bagian tertentu, Sapardi menghadirkan Marah Rusli, pengarang Siti Nurbaya sebagai salah satu tokoh dalam novel Pengarang Tak Pernah Mati . Inilah be berapa hal yang menarik untuk dibahas dalam artikel hasil pene litian ini.

\section{B. KAJIAN TEORI}

Dekonstruksi dari akar kata de + constructio (Latin). Pada umumnya prefiks 'de' berarti ke bawah, pengurangan, terlepas dari. Constructio berarti: bentuk hal, susunan, menyusun, hal mengatur. Jadi, dekostruksi dapat diartikan sebagai pengurangan atau penurunan intensitas bentuk yang sudah tersusun, sebagai bentuk yang sudah baku. Sebagaimana sering terjadi dalam menerjemahkan istilah-istilah asing, dengan adanya perbedaan perbendaharaan kata-kata, maka sangat sulit untuk menemukan terjemahan yang tepat terhadap istilah dekonstruksi tersebut. Dalam teori kontemporer istilah dekonstruksi sering diartikan sebagai pembongkaran, perlucutan, penghancuran, penolakan dan berbagai istilah dalam kaitannya dengan penyempurnaan arti semula (Ratna: 2011).

Kristeva menjelaskan bahwa dekostruksi merupakan gabungan antara hakikat destruktif dan konstruktif. Dekonstruksi adalah cara membaca teks sebagai strategi. Dekonstruksi tidak semata-mata ditunjukkan terhadap tulisan, tetapi semua pernyataan kultural sebab keselurahan pernyataan tersebut mengandung teks yang dengan sendirinya sudah mengandung nilai-nilai, prasyarat, ideologi, kebenaran dan tujuantujuan tertentu. Dekonstruksi dengan demikian tidak terbatas hanya melibatkan diri dalam kajian wacana, baik lisan maupun tulisan, melainkan juga kekuatan-kekuatan lain yang secara efektif menstrasformasikan hakikat wacana.

Menurut Al-Fayyadi (2011:232) dekonstruksi adalah testimoni terbuka kepada mereka yang kalah, mereka yang terpinggirkan oleh stabilitas rezim bernama pengarang. Maka, sebuah dekostruksi adalah gerak perjalanan menuju hidup itu sendiri. 
Sarup (2011:49) menjelaskan bahwa dekonstruksi menurut Derrida merupakan sebuah metode membaca teks secara sangat cermat hingga pembedaan konseptual hasil ciptaan penulis yang menjadi landasan teks tersebut tampak tidak konsisten dan paradoks dalam menggunakan konsep-konsepnya dalam teks secara keseluruhan. Dengan kata lain, teks tersebut gagal memenuhi kriterianya sendiri; standar atau definis $i$ yang dibangun teks digunakan secara reflektif untuk mengguncang dan menghancurkan pembedaan konseptual awal teks itu.

Cara baca Derrida atas teks-teks filosof is ada lah yang hendak melacak struktur dan strategi pembentukan makna di balik tiap teks itu, antara lain dengan jalan membongkar sistem perlawanan-perlawanan utama yang tersembunyi di dalamnya. Pembacaan dekostruktif hendak menunjukkan ketidakberhasilan ambisi filsafat untuk lepas dari tulisan, yaitu menunjukkan agenda tersembunyi yang mengandung banyak kelemahan dan kepincangan di balik teks-teks. Oleh karena itu, Derrida meyakini bahwa di balik teks filosofis yang terdapat bukanlah kekosongan, melainkan sebuah teks lain. Suatu jaringan keragaman kekuatan-kekuatan yang pusat referensinya tidak jelas.

Tugas dekonstruksi menurut Derrida (Norris, 2006:56) adalah menghilangkan ide-ide ilusif yang selama ini menguasai metafisika Barat yaitu ide yang mengatakan rasio bisa lepas dari bahasa dan sampai kepada kebenaran atau metode murni yang otentik dalam diriya sendiri tanpa bantuan yang lain. Sementara itu, Al-Fayyadi (2006:64) mengemukakan bahwa cara strukturalisme memilah bahasa dalam pandangan Derrida telah usang dan tidak memadai. Bahasa tidak selalu hadir dalam wajah tunggal yang koheren. Dekonstruksi Derrida ingin memerdekakan kembali kekuatan bahasa dengan memaksimalkan permainan tanda yang kurang banyak mendapat perhatian dari kaum strukturalis dan bahkan cenderung dihindari. Derrida selalu melihat bahasa sebagai medan di mana makna dan tanda berebut untuk tampil ke permukaan teks.

Menurut teori bahasa Derrida, penanda (signifier) tidak berkaitan langsung dengan petanda (signified). Petanda dan penanda tidak berkorespondensi satu-satu. Menurut pemikiran Saussure, tanda dilihat sebagai satu kesatuan, tetapi menurut Derrida, pada kenyataannya kata dan benda atau pemikiran tidak pernah menjadi satu. Derrida melihat tanda sebagai struktur perbedaan: sebagian darinya selalu "tidak di sana", dan sebagian yang lain selalu "bukan yang itu". Dengan kata lain, Derrida 
mengatakan, ketika membaca suatu penanda, makna tidak serta merta menjadi jelas. Penanda menunjuk apa yang tidak ada, maka dalam arti tertentu makna juga tidak ada. Makna terus menerus bergerak di sepanjang mata rantai penanda dan tidak dapat dipastikan "posisi" persisnya, karena makna tidak pernah terikat pada satu tanda tertentu. Makna tidak pernah identik dengan dirinya sendiri karena muncul pada konteks yang berbeda-beda, tanda tidak pernah memiliki makna yang mutlak sama. Makna tidak akan pernah sama dari satu konteks ke konteks yang lain. Petanda akan selalu diubah oleh berbagai macam mata rantai yang menjeratnya (Sarup, 2008:47). Dengan demikian, tanda akan se lalu mengarah pada tanda lain, satu tanda akan selalu mengarah pada tanda lain, satu tanda akan saling menggantikan tanda yang lain sebagai petanda dan penanda.

Satu hal yang penting dalam dekonstruksi menurut Derrida adalah penolakannya terhadap pusat. Strukturalisme selalu mengutamakan adanya pusat, artinya pusat menguasai pusat. Dekonstruksi menolak pemusatan tersebut dengan cara terus-menerus berusaha melepaskan diri sekaligus mencoba menemukan pusat-pusat yang baru. Menurut Derrida, dalam usaha menemukan pusas-pusat yang baru sesungguhnya subjek juga akan selalu terlibat dengan adanya satu pusat.

Hal yang perlu diperhatikan adalah, di satu sisi pusat itu adalah plural, bukan tunggal. Di pihak lain, yang dimaksudkan adalah fungsi, bukan realitas. Untuk menjelaskan maksud ini, Derrida mengemukakan konsep decentering, struktur tanpa pusat dan tanpa hierarki. Cara yang dilakukannya, misalnya dengan memahami dan mengkaji sesuatu yang semula dianggap kurang penting, misalnya tokoh sekunder, tema minor, dan sebagainya, bahkan pada ruang-ruang kosong sehingga mempengaruhi seluruh isi teks dan semesta sosial sehingga pusat bergeser terus menerus. Dalam kaitan inilah dekonstruksi membongkar sistem hierarki, sistem logika yang sudah dianggap baku.

Masalah lain dalam dekonstruksi adalah penggembosan terhadap narasi besar (grand narative). Sesuatu yang telah berlaku lama, tertata, kemudian muncul sesuatu yang baru yang menolak atau bahkan sama sekali bertolak belakang dengan apa yang selama ini sudah tertanam kokoh, baik di bidang sosial, politik, agama, budaya, begitu juga dalam sastra. Hal ini dapat dilihat dari munculnya karya-karya sastra yang menolak pola-pola "baku" memang berlaku dalam penulisan sebuah karya sastra 
selama ini, baik mengenai tokoh, tema, setting, peristiwa, logika cerita, dan lain sebagainya. Dari susunan rapi dan tertata itu, dekonstruksi mendobrak atau "merusak" konstruksi untuk menghasilkan konstruksi baru.

Derrida mengemukakan beberapa gagasan kunci dalam dekonstruksi, yaitu :

1. Differance, berarti berbeda atau menangguhkan. Differance merupakan gagasan kunci Derrida untuk menjelaskan instabilitas bahasa. Bahasa dalam wawasan differance, disusun dari perbedaan-perbedaan yang menunda makna. Struktur bahasa menurut Derrida adalah sesuatu yang dinamis atau senantiasa 'bergerak" melalui proses perbedaan dan penundaan. Arti suatu tanda bergantung pada perbedaan dan penundaannya dengan relasi lain dalam ruang dan waktu. Dengan kata lain, suatu tanda tidak akan pernah mencapai makna secara penuh karena proses perbedaan dan pe nangguhan yang senantiasa berlangsung.

2. Trace atau tilas, berkaitan dengan tanda yang selalu merupakan tilas dari tanda lain. Suatu tanda tidak pernah benar-benar memiliki arti pada dirinya sendiri, kecuali dalam hubungannya dengan tanda-tanda yang lain. Tidak ada tanda yang memiliki arti secara otonom sebab tilas dari tanda lain selalu menjadi bagian yang menyatu di dalam identitas diri dari suatu tanda. Dalam konteks bahasa, arti dari suatu konstruksi kalimat juga ditentukan oleh medan asisiatif atau sumbu paradigmatik dari kata-kata yang tidak hadir. Dengan kata lain, yang hadir, ditentukan yang tidak hadir. Tilas dari tanda-tanda lain akan selalu membayangi suatu tanda.

3. Suplemen, yaitu bahasa selalu mengalami penambahan atau subtitusi. Derrida mengatakan bahwa suatu bahasa pada dasarnya adalah tulisan. Hal ini bermakna, segala bentuk bahasa, termasuk tuturan, tidak pernah bersifat langsung karena diperantarai oleh medium yakni tanda-tanda. Derrida mengatakan, proses splementasi akan terus berlangsung dalam bahasa karena sejak awal suatu tanda tidak cukup-diri (incomplete), dan selalu ada penambahan dan penggantian pada tanda-tanda.

4. Teks, yaitu keseluruhan realitas dianggap sebagai teks. Bagi Derrida, tidak ada sesuatu yang di luar teks, sehingga sang pusat juga tidak bisa mengklaim lebih dominan, karena ia hanyalah salah satu dari jaringan teks. Realitas sesungguhnya tidak ada karena semua realitas dikonstruksi secara budaya, linguistik, atau historis, adalah teks. 
5. Desiminasi, yakni persebaran makna. Makna bagi Derrida tidak terpaut dengan satu petanda melainkan bersifat temporer karena relasi antartanda yang menyusun bahasa bersifat tidak statis.

6. Ketiadaan putusan, yakni teks dan pembaca tidak terpisah dari ikatan desiminasi atau persebaran makna bahasa. Makna tertentu hanyalah momen dari makna yang yang memberikan jalan -yang tidak terhindarkan- kepada makna lainnya.

\section{METODE PENELITIAN}

Penelitian ini merupakan penelitian kualitatif. Menurut Bogdan dan Taylor (Margono, 2007:26), penelitian kualitatif adalah adalah prosedur penelitian yang menghasilkan data deskriptif berupa kata-kata tertulis atau lisan dari orang-orang atau perilaku yang dapat diamati. Sumber data penelitian ini adalah novel karya Sapardi Djoko Damono berjudul Trilogi Soekram, khususnya bab 'Pengarang Tak Pernah Mati'. Trilogi Soekram merupakan trilogi yang diambil dari tiga novel yang terpisah, yaitu Pengarang Telah Mati, Pengarang Belum Mati, dan Pengarang Tak Pernah Mati.

Pengumpulan data dilakukan dengan metode kepustakaan. Novel sebagai dokumen tertulis dibaca secara cermat. Teknik yang digunakan ada lah teknik catat. Data yang dikumpulkan dengan teknik catat ini berkaitan dengan aspek dekonstruksi tokoh utama yang ada di dalamnya. Pengumpulan data memanfaatkan instrumen penelitian. Oleh karena penelitian ini merupakan penelitian teks sastra dan bersifat kualitatif, instrumen terpenting dalam penelitian ini adalah peneliti sendiri. sebagai human instrument peneliti berfungsi menetapkan fokus penelitian, memilih informan sebagai sumber data, melakukan pengumpulan data, menilai kualitas data, menganalis is data, menafsirkan data dan membuat kesimpulan atas temuan penelitian (Sugiono, 2013:306). Analis is data dilakukan dengan menerapkan teori dekonstruksi. Analis is dilakukan dengan berusaha memberi interpretasi terhadap aspek linguistik dan peristiwa-peristiwa yang ada dalam novel.

\section{HASIL DAN PEMB AHASAN}

Roman Siti Nurbaya karya Marah Rusli dan Salah Asuhan karya Abdul Muis merupakan dua di antara beberapa roman Angkatan Balai Pustaka. Dua roman ini yang merupakan grand narative, semacam narasi besar yang telah dipahami dan diketahui 
masyarakat umum di Indonesia. Kedua roman ini telah dikenal luas. Kisah-kisah yang terjadi dan tokoh-tokoh yang terlibat di dalamnya telah diketahui khalayak, sehingga ketika ada kisah yang berbeda, apalagi dengan karakter tokoh yang berbeda, akan memunculkan pertanyaan bahkan perdebatan dalam masyarakat yang pernah membaca kedua roman tersebut.

Sapardi Djoko Damono melalui novel Trilogi Soekram bab 'Pengarang Tak Pernah Mati' (selanjutnya akan disingkat menjadi PTPM) melakukan dekonstruksi terhadap tokoh-tokoh sentral kedua roman tersebut. Tokoh Datuk Meringgih (di bagian awal PTPM namanya disebut secara lengkap namun di bagian-bagian berikutnya disebut Datuk saja), Siti Nurbaya (dalam PTPM hanya disebut sebagai Nurbaya), dan Samsulbahri (dalam PTPM disebut Samsul dan Massul) didekonstruksi karakternya.

Dalam roman Siti Nurbaya, Datuk Meringgih dikenal sebagai saudagar kaya yang licik dan kasar. Hal ini terlihat dalam kutipan berikut.

Saudagar ini adalah orang yang bakhil, loba dan tamak, tiada pengasih dan penyayang, serta bengis kasar budi pekertinya. (hal.84).

Dalam PTPM, karakter Datuk Meringgih didekonstruksi menjadi tokoh agama berwibawa. Hal ini misalnya tampak pada penggalan berikut.

Soekram diam saja, memandang janggut dan kadang-kadang misai Datuk, tak pernah berani menatap matanya. Tidak karena takut kualat, tetapi karena wibawa pemimpin umat ini terpusat pada matanya yang bahkan kalau menatap mata kucing anggora, misalnya, binatang itu pun akan langsung cabut. Janggutnya yang putih sempurna, di samping misainya, menyiratkan kekuatan yang ditopang oleh usia yang melampaui tampang dan tenaga hidupnya perempuan-perempuan muda di nagari manapun akan terpesona jika ia menyampaikan khotbah tentang betapa lic iknya Belanda dan betapa miskinnya pengetahuan bangsa kita ini tentang politik. (PTPM hal. 154-155).

Datuk adalah tokoh agama yang selalu dirindukan sehingga kehadirannya ditunggu-tunggu warga (hal. 195-196). Datuk adalah tokoh kharismatik yang sangat yakin akan kekuasaaan Allah, surau adalah rumahnya walaupun banyak rumah yang dimilikinya ( hal. 230). Dalam Siti Nurbaya, Datuk Meringgih digambarkan sebagai lelaki tua yang belum menikah karena berwajah buruk dan berwatak culas. Dalam PTPM, Datuk justru digambarkan sengaja menunda-nunda untuk menikah walau usianya tua (ha1.219, 233), padahal banyak gadis yang terpesona olehnya (hal. 155). 
Tokoh Siti Nurbaya dalam Siti Nurbaya adalah perempuan muda yang tidak menyukai Datuk Meringgih dan sangat menghormati kedua orang tuanya. Untuk membela martabat ayahnya dan menghindarkann ayahnya dari pemenjaraan yang akan dilakukan Datuk Meringgih, ia berkorban mau dinikahi lelaki tua itu (hal. 119). Dalam PTPM, Nurbaya justru digambarkan karakternya sebagai perempuan muda yang mencintai Datuk (hal. 174, 229) dan mendukung perjuangan Datuk me lawan penindasan penjajah. Bahkan demi mendukung perjuangan Datuk, ia bertekad melawan orang tuanya jika ia dilarang mendukung Datuk, seperti kutipan berikut.

Namun, kata Datuk, gadis itu sudah terlanjur jatuh cinta kepada perjuangannya. Ia bahkan, kata Datuk, siap mengorbankan apa saja demi perjuangan itu. Ketika Datuk menanyakan hal hubungannya dengan Samsul itu kepadanya, jawabnya, apalagi cuma Sam, ayah pun akan saya lawan kalau menghalangi-halangi perjuangan kita. (PTPM hal. 172)

Selanjutnya, Nurbaya dan Datuk berjuang bersama. Kebersamaan meraka bahkan digambarkan dalam satu subbab tersendiri oleh Sapardi (hal. 255-263), hubungan mereka sangat dekat (hal. 263), sehingga dalam kondisi tertentu, Nurbaya sangat mengkhawatirkan dan bertanggung jawab terhadap kondisi Datuk.

Paginya, sebelum tiba di kampung yang dituju, Nurbaya tiba-tiba menjadi sangat khawatir akan laki-laki tua yang menjadi tanggung jawabnya itu. Datuk tampak diam, murung. Pasti sedang memikirkan sesuatu. Tapi Nurbaya menunggu saat yang baik untuk memulai pembicaraan. Akhirnya diberani-beranikan juga dirinya untuk mengajukan pertanyaan.

"Datuk, mengapa tiba-tiba saja tampak seperti tertekan, justru di saatsaat yang menentukan ini? Belum pernah saya melihat Datuk tampak murung seperti sekarang ini. Apakah gerangan yang ada dalam pikiran Datuk? Peristiwa di hutan semalam yang menguras tenaga kita itu? Berita merapatnya armada di pelabuhan? Datuk te lah mengajarkan sifat-s ifat ksatria kepada kami. Datuk telah menanamkan rasa percaya diri kepada kami, dan kami telah siap menunggu apa yang Datuk perintahkan kepada kami. (PTPM hal. 266).

Kedekatan hubungan antara Nurbaya dan Datuk dalam PTPM di atas sangat berbeda dengan kisah dalam Siti Nurbaya. Dalam roman tersebut hubungan antara keduanya sama sekali tidak pernah baik, bahkan walaupun Siti Nurbaya telah dinikahi oleh Datuk Meringgih (hal 154-155).

Penguabahan karakter Datuk Maringgih yang dilakukan Sapardi Djoko Damono dalam PTPM sejalan dengan pandangan Nurgiantoro (2012: 60) yang memberi penjelasan tentang dekonstruksi tokoh. Ia menjelaskan, seorang tokoh cerita yang tidak 
penting berhubung hanya sebagai tokoh periferal, tokoh (kelompok) pinggiran saja, setelah didekostruksi ia menjadi tokoh yang penting, yang memiliki fungsi dan makna yang menonjol sehingga tak dapat ditinggalkan begitu saja dalam memaknai karya itu. Faruk (2001:182) menjelaskan hal seperti itu sebagai "pembalikan oposisi-oposisi yang sudah klasik, peme lesetan besar-besaran terhadap sistem itu secara keseluruhan".

Tokoh lain sentral dalam roman Salah Asuhan yang diangkat oleh Sapardi dalam TPTM adalah Hanafi. Karakter Hanafi dalam Salah Asuhan adalah sebagai pemuda yang terpengaruh adat kebiasaan barat. Karakter ini sama dengan Hanafi dalam PTPM, namun yang berbeda dalam PTPM adalah bahwa Hanafi justru digambarkan bersaudara dengan Nurbaya, karena ia adalah kakak dari Nurbaya (hal. 185). Hanafi dikisahkan bersahabat dengan Samsulbahri (kekasih Siti Nurbaya dalam Siti Nurbaya).

Karakter tokoh yang juga didekonstruksi Sapardi adalah ayah Nurbaya. Dalam Siti Nurbaya, tokoh ayah yang bernama Baginda Sulaiman ini digambarkan sebagai le laki yang memperoleh kekayaan dengan berniaga, yang kemudian jatuh miskin karena difitnah dan diakali oleh Datuk Meringgih (hal. 92). Dalam PTPM, ayah Nurbaya justru dilukiskan sebagai collecteur pajak (hal. 173, 183, 186, 190) dan kaki tangan pemerintah. Kematian ayah Nurbaya pun didekonstruksi oleh Sapardi. Jika dalam Siti Nurbaya sang ayah meninggal karena jatuh dari tangga saat sakit (hal. 154), dalam PTPM ayah Nurbaya disebut mening gal bunuh diri karena malu. Hal ini diketahui dari dialog Nurbaya kepada Soekram di bawah ini.

"Hanafi berfoya-foya, menghabiskan duit. Utang sana-sini, akhirnya pulang membujuk ibu nyuri uang setoran pajak di brangkas untuk membayar utang. Kembali lagi ke Betawi, begitu lagi, akhirnya ditangkap polisi karena ayah dan ibu tak mau lagi bertanggung jawab - ketika Uda Hanafi dalam sekapan polis $i$ itulah ayah bunuh diri. Ayah malu, benar-benar malu." (PTPM hal. 188)

Dalam PTPM, Sapardi menghadirkan tokoh Kartini. Ia dic eritakan sebagai puteri Datuk Maringgih, saudara dari Datuk Meringgih (hal. 187). Kartini digambarkan Sapardi sebagai perempuan terpelajar yang sering menulis surat kepada seorang nyanya Belanda. Hal ini tampak da lam pernyataan Nurbaya ketika berbicara dengan Soekram.

"Kartini ini sahabatku sejak sekolah, suka menulis surat kepada seorang nyonya Belanda di Betawi, katanya bicara tentang berbagai hal: adat, agama, pendidikan, perkawinan. Dalam bahasa Belanda surat-suratnya itu. Suka membanding-bandingkan apa yang ada di Eropa sana dan di sini, suka kadang- 
kadang membantah guru dalam kelas, suka mengajakku tamasya ke Gunung Padang juga, Kram.” (PTPM hal 187)

Kutipan karakter tokoh Kartini di atas identik dengan pejuang emansipasi Indonesia, Raden Ajeng Kartini. Dalam sejarah Indonesia, R.A. Kartini dikenal sebagai perempuan yang memperjuangkan hak-hak perempuan. Untuk memperkuat dan mendukung perjuangannya Raden Ajeng Kartini sering berkomunikasi melalui surat dengan beberapa perempuan Belanda seperti Nyonya Abendanon dan Nyonya Van Kol (Sutrisno, 1985).

Dekonstruksi berarti positif karena membongkar dan menjungkirbalikkan makna teks tapi bukan dengan tujuan membongkar saja, melainkan membangun teks atau wacana baru dengan makna yang baru (Lubis, 2014:34). Upaya membongkar dan menjungkirbalikkan teks itu dalam PTPM tampak pula dari kehadiran tokoh Marah. Tokoh ini identik dengan Marah Rusli, pengarang roman Siti Nurbaya. Artinya, Sapardi Djoko Damono telah melakukan hal yang selama ini tidak lazim dilakukan pengarang, yaitu menjadikan pengarang suatu karya sastra menjadi tokoh dalam karya sastra yang lain. Kehadiran tokoh Marah dalam PTPM dilihat pada kutipan berikut, yaitu dialog Soekram dengan Marah.

"Namaku Marah."

"Marah kepada siapa?"

"Aku ini makhluk yang oleh orang tuaku diberi nama Marah! Paham?"

"Tapi saya tidak punya saudara, apa lagi yang bernama Marah."

"Sudah kubilang, aku ini kakakmu. Aku sebenarnya sudah tahu mau apa kamu lewat di sini." (PTPM hal. 251-252)

Pernyataan 'aku ini kakakmu' pada kalimat terakhir kutipan di atas menunjukkan posisi mereka sebagai sesama pengarang: Marah sebagai pengarang Siti Nurbaya, Soekram sebagai pengarang Nurbaya. Hal ini dipertegas dengan adanya dialog keheranan tokoh Soekram karena Marah sangat mengenal Nurbaya dan Datuk.

"Jadi Anda mengenal mereka?"

"Bukan hanya kenal, Kram. Akulah yang dulu menciptakan mereka." (PTPM hal. 252)

Beberapa aspek dekonstruksi yang ditemukan dalam novel PTPM di atas menunjukkan bahwa teks sastra, dalam hal ini roman Siti Nurbaya dan Salah Asuhan dipahami dalam arti kebalikannya. Unsur-uns ur yang “tidak penting”, misalnya tokoh 
Datuk Meringgih yang dianggap antagonis dalam Siti Nurbaya, dilacak dan kemudian "dipentingkan", diberi makna, peran, sehingga akan terlihat (atau: menonjol) perannya dalam karya yang bersangkutan. Jika dalam Siti Nurbaya Datuk Meringgih merupakan tokoh antagonis, maka dalam PTPM, Datuk Meringgih adalah tokoh sentral yang menjadi panutan. Pengubahan karakter yang dilakukan Sapardi da pat dimaknai sebagai upaya Sapardi mengkritisi tokoh dan karakternya dalam roman yang selama ini dipahami dan diyakini masyarakat pembaca. Dari aspek dekonstruksi, hal ini sejalan dengan pandangan Lubis (2014:35) yang mengatakan bahwa dekontruksi merupakan upaya untuk mengkritisi secara radikal dan membongkar berbagai asumsi dasar yang menopang keyakinan dan pemikiran selama ini.

Teks sastra, Siti Nurbaya dan Salah Asuhan yang menggunakan medium bahasa berusaha dipahami maknanya justru dengan menghadirkan sisi kebalikannya. Analisis di atas telah menunjukkan bagaimana dengan medium bahasa dalam karyanya, Sapardi menghadirkan aspek-aspek yang bertolak belakang dengan teks semula. Hal ini sesuai dengan pandangan Derrida sebagai tokoh dekonstruksi yang menyatakan bahwa bahasa secara esensial adalah sistem "penanda" (simbol) yang mendapatkan makna mereka bukan dari keterkaitan dengan dunia yang ingin mereka wakili, namun hanya dengan konteks hubungan internal mereka dengan "perbedaan" (Agger, 2008: 117-118). Dekonstruksi secara tegas menolak pandangan bahwa bahasa memiliki makna yang pasti, tertentu, dan konstan (Ronidin, 2015:39). Makna bahasa tidak teratur, tidak stabil, dan tergantung konteks. Bahasa tidak bersifat memaksa melainkan subversif dekonstruktif (Ritzer dan Goodman, 2004:608).

Perlu ditegaskan di sini bahwa pemberian makna terhadap teks Siti Nurbaya dan Salah Asuhan yang dilakukan oleh sapardi Djoko Damono melalui salah satu novelnya Pengarang Tak Pernah Mati merupakan pemaknaan secara berkelanjutan. Makna suatu teks tak pernah berhenti pada teks itu sendiri. Makna suatu teks akan memunculkan makna-makna baru, bahkan makna tersebut dapat dimodifikasi oleh petanda lain yang muncul kemudian. Sarup (2011: 46-48) mengatakan bahwa ketika membaca kalimat, makna sering baru muncul setelah kalimat itu selesai dibaca; bahkan makna tersebut dapat saja dimodifikasi oleh penanda yang muncul kemudian. Pada setiap tanda terdapat jejak-jejak kata-kata la in yang dipinggirkan tanda tersebut agar tanda tersebut dapat menjadi dirinya sendiri. Setiap kata juga memuat jejak kata yang 
telah hilang sebelumnya. Setiap kata dalam kalimat, setiap tanda dalam matarantai makna, memiliki jejak-jejak tersebut dalam kompleksitas yang tidak ada habisnya. Makna tidak pernah identik dengan dirinya sendiri karena muncul pada konteks yang berbeda-beda, tanda tidak pernah memiliki makna yang mutlak sama. Makna tidak akan pernah sama dari satu konteks ke konteks yang lain; petanda akan selalu diubah oleh pelbagai macam matarantai yang menjeratnya.

\section{E. SIMPULAN}

Analisis di atas menunjukkan bahwa terdapat dekonstruksi tokoh dalam novel Trilogi Soekram bab 'Pengarang Tak Pernah Mati' karya Sapardi Djoko Damono. Tokoh-tokoh yang dihadirkan dalam novel tersebut merupakan dekonstruksi terhadap tokoh-tokoh yang ada dalam dua roman Angkatan Balai Pustaka yaitu Siti Nurbaya dan Salah Asuhan seperti Datuk Meringgih, Siti Nurbaya, dan Hanafi. Tokoh-tokoh tersebut didekonstruksi karakternya, bahkan tokoh dari dua roman yang berbeda dipertemukan dalam novel Sapardi tersebut. Hal tersebut menunjukkan bahwa sesuai dengan konsep dekonstruksi, makna sebuah teks tidak pernah berdiri sendiri dan tidak pernah mutlak. Makna sebuah teks dapat berubah, bahkan menjadi sebaliknya. Sapardi tidak hanya telah membongkar teks sebelumnya (Siti Nurbaya dan Salah Asuhan), melainkan juga telah membangun teks baru dengan makna baru yang berbeda dengan teks yang didekonstruksi. Hal yang dilakukan Sapardi merupakan bentuk yang bertolak belakang dengan pemahaman masyarakat terhadap tokoh, karakter, dan alur kisah dalam Siti Nurbaya dan Salah Asuhan. Pengubahan peran dan karakter tokoh yang dilakukan Sapardi Djoko Damono merupakan bentuk kreativitas. Berkaitan dengan hal itu, pene liti menyarankan agar pengarang selalu mengembangkan kreativitas sebagai respon terhadap perkembangan dan perubahan dalam masyarakat maupun dalam dunia sastra. Kreativitas tersebut akan muncul di antaranya dengan banyak membaca karya-karya sastra yang sudah ada.

\section{DAFTAR PUSTAKA}

Al-Fayyadl, Muhammad. 2006. Derrida. Yogyakarta: Lkis.

Agger, Ben. 2008. Teori Sosial Kritis, Penerapan dan Implikasinya. Terj. Nurhadi. Yogyakarta: Krasi Wacana. 
Damono, Sapardi Djoko. 2015. Trilogi Soekram. Jakarta: Gramedia Pustaka Utama.

Faruk, H.T. (ed.)2001. Metodologi Penelitian Sastra. Yogyakarta: Hanindita Graha Widia.

Lubis, Akhyar Y usuf. 2014. Postmodernisme: Teori dan Metode. Jakarta: RajaGrafindo Persada

Moe is, Abdoel. 2003. Salah Asuhan. Jakarta: Balai Pustaka.

Norris, Christoper. 2006. Membongkar Teori Dekonstruksi Jacques Derrida (Terj. Inyiak Ridwan Muzir). Yogyakarta: Arruz Media.

Nurgiyantoro, Burhan. 2012. Teori Pengkajian Fiksi. Yogyakarta: Gadjah Mada University Press.

Ratna, Nyoman Kutha. 2011. Teori, Metode, dan Teknik Penelitian Sastra. Yogyakarta: Pustaka Pelajar.

Ritzer, George dan J. Goodman. 2004. Teori Sosiologi Modern. Jakarta: Prenada Media.

Ronidin. 2015. 'Pembacaan Dekonstroksi Cerpen 'Zina' Karya Putu Wijaya”. Jurnal Puitika. Volume 11 No. 1 April 2015.

Rusli, Marah. 2001. Siti Nurbaya. Jakarta: Balai Pustaka.

Sarup, Madan. 2011. Panduan Pengantar untuk Memahami Postsrukturalisme dan Postmodernisme. Yogyakarta: Jalasutra.

Sutrisno, Sulastin (pent.). 1985. Surat-Surat Kartini: Renungan tentang dan untuk Bangsanya. Jakarta:Djambatan. 